\title{
Socio-environmental risks associated with the green tobacco sickness in farmers: a case-control study
}

Riscos socioambientais associados à doença da folha verde do tabaco em agricultores: um estudo caso-controle

Riesgos socioambientales asociados a la enfermedad del tabaco verde en agricultores: un estudio caso-control

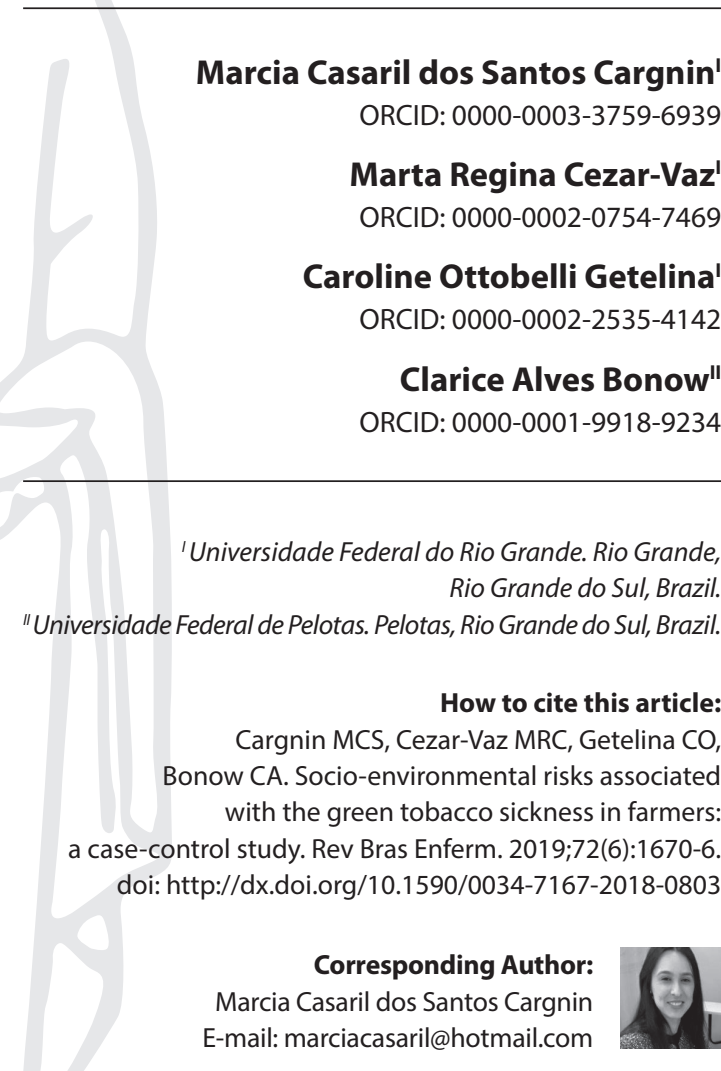

Submission: 10-15-2018 Approval: 03-25-2019

\begin{abstract}
Objective: to determine the presence of socio-environmental risk factors for the development of Green Tobacco Sickness in workers who grow Burley tobacco. Method: matched case-control study. The data collection took place in two moments: from December 2016 to January 2017 and December 2017, when the Burley tobacco was collected, through a household survey with interview application and urine collection for urinary cotinine. Results: the socio-environmental risk factors that remained associated with the disease were: bundling tobacco $(p=0.047)$ and wearing socks $(p=0.011)$; with protective effect were found sticking tobacco seeding of the day $(p=0.006)$ and number of tobacco harvested per day $(p=0.021)$. Conclusion: the steps in the Burley tobacco work process increase the exposure and risk of developing the disease. By identifying these factors, it is possible to address interdisciplinary control and prevention measures.
\end{abstract}

Descriptors: Risk; Farmers; Tobacco; Occupational Exposure; Nursing.

\section{RESUMO}

Objetivo: determinar a presença de fatores de riscos socioambientais para o desenvolvimento da Doença da Folha Verde do Tabaco em trabalhadores que cultivam o tabaco Burley. Método: estudo do tipo caso-controle pareado. A coleta de dados ocorreu em dois momentos: de dezembro de 2016 a janeiro de 2017 e dezembro de 2017, período em que ocorreu a colheita do tabaco Burley, por meio de inquérito domiciliar com aplicação de entrevista e coleta de urina para exame de cotinina urinária. Resultados: os fatores de riscos socioambientais que permaneceram associados à doença foram enfeixar tabaco $(p=0,047)$ e usar meias $(p=0,011)$; com efeito protetor foram encontrados espetar pés de tabaco do dia $(p=0,006)$ e número de pés de tabaco colhido por dia $(p=0,021)$. Conclusão: as etapas do processo de trabalho com tabaco Burley aumentam a exposição e o risco de desenvolver a doença. Ao identificar esses fatores, é possível direcionar, de forma interdisciplinar, medidas de controle e prevenção.

Descritores: Risco; Agricultores; Tabaco; Exposição Ocupacional; Enfermagem.

\section{RESUMEN}

Objetivo: determinar la presencia de factores de riesgo socioambientales para el desarrollo de la Enfermedad del Tabaco Verde en trabajadores que cultivan el tabaco Burley. Método: estudio del tipo caso-control pareado. La recolección de datos ocurrió en dos momentos: de diciembre de 2016 a enero de 2017 y diciembre de 2017, período en que ocurrió la recolección del tabaco Burley, por medio de encuesta domiciliaria con aplicación de entrevista y recolección de orina para el examen de cotinina urinaria. Resultados: los factores de riesgo socioambientales que permanecieron asociados a la enfermedad fueron aferrar tabaco $(p=0,047)$ y usar medias $(p=0,011)$; con efecto protector fueron encontrados espetar los pies de tabaco del día $(p=0,006)$ y el número de pies de tabaco cosechados por día $(p=0,021)$. Conclusión: las etapas del proceso de trabajo con tabaco Burley aumentan la exposición y el riesgo de desarrollar la enfermedad. Al identificar estos factores, es posible dirigir, de forma interdisciplinaria, medidas de control y prevención.

Descriptores: Riesgo; Agricultores; Tabaco; Exposición Ocupacional; Enfermería. 


\section{INTRODUCTION}

Brazil is the leader in exports of tobacco and the second largest worldwide producer of this plant. The Brazilian state that stands out as the largest producer of the plant ${ }^{(1)}$ is Rio Grande do Sul (RS). Tobacco production setting has harmful implications for the environment and the health of the families involved ${ }^{(2)}$. Among the health problems, the risk of developing Green Tobacco Sickness (GTS) stands out ${ }^{(3)}$ as an occupational disease observed among tobacco workers ${ }^{(4)}$ caused by the dermal absorption of nicotine at the time of cutting tobacco leaves in the field and in the leaves ${ }^{(5)}$, as well as by the inhalation of nicotine from the air in the various environments of tobacco workers ${ }^{(6)}$.

Symptoms described in the literature ${ }^{(3,7)-8)}$ are weakness, headache, vomiting, nausea, dizziness, colicky and abdominal pain, difficulty breathing, paleness, diarrhea, fainting, chills, changes in blood pressure and heart rate during or after exposure, increased respiration and salivation, abnormal body temperature and excessive sweating. Nausea and weakness may occur within 15 minutes after contact with the $\operatorname{skin}^{(4)}$, with signs and symptoms usually occurring after work for 3 and 17 hours, and may vary. Diagnosis is based on the triad: presence of compatible signs and symptoms such as those already listed, history of exposure to tobacco culture and high levels of nicotine by measuring the cotinine level ${ }^{(9-10)}$.

In this sense, it is necessary to know the clinical manifestations, risks and health impacts of workers in the tobacco work process. Thus, from this knowledge, it is possible to develop interventions that include the worker and his family in actions and practices of disease prevention, protection and health promotion in Primary Health Care.

Among the risk factors for the development of GTS are tobacco picking or sprout thinning, which consists of the removal of the flower from the plant, contact with the damp tobacco leaves at harvest ${ }^{(11)}$, and lack of experience in working with tobacco ${ }^{(5)}$. Other factors such as working in hot and humid weather conditions, pre-existing epidermal and/or cutaneous lesions, and consuming alcohol after work are factors that facilitate the absorption of nicotine ${ }^{(12-13)}$. In addition, the chemical and toxicological characteristics of tobacco leaf are factors that can determine the presence of the disease ${ }^{(14)}$.

During harvesting, wearing protective clothing such as waterproof clothing (gloves and waterproof clothing), gloves, boots and socks and avoiding working with tobacco and wet clothing are protective measures that would reduce the risk of disease onset ${ }^{(5,9)}$. The work carried out by tobacco workers exposes them to the risks that are produced by the conditions and the work organization ${ }^{(15)}$, being a socio-environmental condition that influences the health and illness conditions of workers ${ }^{(16)}$. In this context, the broad relationship of several socio-environmental factors - the plant, the worker and the work environment - participate in the determination of GTS.

In view of the above, the development of this study is justified, since it seeks to identify the socio-environmental risk factors in the work process for the development of GTS in workers of Burleytype tobacco allows to recommend to the workers measures of control and prevention of the disease. These measures help reduce the exposure to the factors that trigger the signs and symptoms, mainly because Burley-type tobacco contains 3 to 4 times more nicotine than Virginia-type tobacco ${ }^{(3)}$. It is also worth noting that studies on GTS in Brazilian farmers have associated the risks to Virginia-type tobacco. Thus, this research contributes to future studies, as an example, comparative studies between the two types of tobacco.

\section{OBJECTIVE}

To determine the presence of socio-environmental risk factors for the development of Green Tobacco Sickness in workers who grow Burley tobacco.

\section{METHOD}

\section{Ethical aspects}

The research was approved by the Research Ethics Committee of the proposing institution, the Universidade Regional Integrada do Alto Uruguai e das Missões, and the co-participating institution, the Universidade Federal do Rio Grande (UFRG). All norms established by Resolution 466/12 were respected and all participants signed the Free and Informed Consent Form.

\section{Design and place of study}

It is a case-control study, carried out in a municipality located in the Northwest region of the state of Rio Grande do Sul, Brazil. The municipality is constituted, in the majority $(61 \%)$, by rural properties, based on familiar agriculture, being the tobacco the third product to contribute with the local economy. The STROBE guide was used to guide the methodology.

\section{Population and sample; inclusion and exclusion criteria}

The study population consisted of rural workers who grow Burley-type tobacco and who were working on the tobacco crop at the harvest stage and also in the 7 days prior to the interview. It is a case-control represented by the proportion 1:4, in other words, four controls for each case during the Burley tobacco harvest period. Cases and controls were matched based on smoking status, as tobacco consumption could reduce the occurrence of GTS. For this, it is considered smoker any individual who smokes daily any type or amount of tobacco, for at least six months ${ }^{(17)}$.

Sample size was calculated using the WinPEPI program (Programs for Epidemiologists for Windows), version 11.43. The total number of tobacco-producing families (82) and the number of workers involved (159) in tobacco production were estimated based on three studies ${ }^{(3,10,18)}$. For a significance level of $5 \%$, prevalence of GTS estimated at $20 \%$, a ratio of 4 controls for each case and a minimum Odds Ratio of 4.5, a minimum sample size of 19 cases and 76 controls was obtained, totaling $n=95$ workers.

Inclusion criteria were: being a rural worker who grows Burleytype tobacco; Burley tobacco harvesting stage at the time of the data collection; have worked on Burley tobacco 7 days preceding the interview; no exposure to other varieties of tobacco 7 days prior to the interview; no exposure to pesticides 7 days prior to interview; be 18 years of age or older; and give a urine sample. 
Women who were pregnant and workers who presented mental/ psychological disorders, self-referred by those responsible, were excluded, characteristics that made comprehension impossible to respond to the research tool.

According to the criteria, of the 159 that made up the population, 37 workers were excluded: 8 because they are minors; 1 for being pregnant; 15 for having harvested tobacco in less than 07 days; 5 for participating in tobacco cultivation, less at harvest; 3 for growing tobacco of common type; and 5 because the Burleytype tobacco has been completed. It should be noted that 8 did not want to participate in the study.

\section{Study protocol}

A worker who reported presenting signs and symptoms of acute intoxication (headache, nausea, vomiting, dizziness or weakness) within 48 hours prior to collection of a urine sample was considered a suspect case. Once confirmed, the suspect case presented a cotinine level above $20 \mathrm{ng} / \mathrm{mL}$ for non-smokers; 20 to $50 \mathrm{ng} / \mathrm{mL}$ for passive or occasional smokers; and greater than $50 \mathrm{ng} / \mathrm{mL}$ for smokers, detected by urinalysis, reference values as established by the laboratory. The controls were tobacco workers who did not show any signs and symptoms of acute intoxication (headache, nausea, vomiting, dizziness or weakness) 7 days prior to the interview, according to studies conducted in Brazil ${ }^{(10,18)}$.

Data collection was carried out through a household survey with interview, using a tool with open and closed questions adapted and authorized by the study of Bartholomay et al. ${ }^{(10)}$, covering occupational identification issues, sociodemographic data on GTS, exposure to tobacco, individual characteristics, smoking status, characteristics on alcohol consumption, exposure to pesticides and other exposures. At the same time, the appropriate polyethylene flask was delivered for urine sample collection for urinary cotinine, as well as guidelines on the collection, handling and storage of the sample in a refrigerator; the search of the sample at home was combined by the researcher the following day. In addition, it was carried out, in a spreadsheet, the daily control of the relative air humidity by means of digital Thermo Hygrometer.

A kit was organized for urine collection, containing thermal box, gelox (Thermogel's Gelox replaces ordinary ice with advantages: it stays frozen longer, is reusable, maintains the temperature longer than ice, does not wet when thawed and its content is a non-toxic gel. It is used for transportation and preservation of products that require refrigeration), disposable gloves, urine collector, numerical identification labels to affix to the bottles and tokens for each worker. The worker performed the collection of the first morning urine. After collecting the samples, they were stored for freezing and, in the presence of a certain quantity, packed in an ultrafreezer $\left(-70^{\circ} \mathrm{C}\right)$, in which they remained stored until all samples were collected for later shipment to the Toxicology Laboratory and Pharmacology for analysis.

Data were collected from December 2016 to January 2017 (2016/2017 crop) and December 2017 (2017/2018 crop) to complete the study sample. Urine samples were tested for cotinine using automated High Performance Liquid Chromatography (HPLC) equipment with ultraviolet detector.

\section{Analysis of results, and statistics}

The data were analyzed in the statistical program Statistical Package for Social Sciences (SPSS), version 21.0. Quantitative variables were described by mean and standard deviation or median and interquartile range. Categorical variables were described by absolute and relative frequencies. To compare means, the t-student test was applied. In case of asymmetry, the Mann-Whitney test was used. In the comparison of proportions, the Pearson Chi-Square or Fisher's Exact Tests were applied. For the control of confounding factors, the Multivariate Logistic Regression analysis was used. The criterion for the entry of the variable in the multivariate model was $p<0.20$ in the bivariate analysis and, for the permanence in the final model, those with $p<0.10$. Significance level was $5 \%(p<0.05)$.

\section{RESULTS}

Of the study participants, 23 tobacco workers were defined as suspect cases, of which, 20 cases were confirmed through urinary cotinine; 91 tobacco workers participated as control.

In the univariate analysis, a statistically significant association was found between the disease and sticking tobacco stem of the day $(p=0.001)$, loading tobacco into the shed $(p=0.009)$, cutting tobacco $(p=0.026)$ and bundling tobacco $(p=0.019)$. Activities that were carrying out on the farm such as picking up tobacco stem of the day ( $87.9 \%$ vs. $50 \%)$, loading tobacco into the shed $(90.1 \%$ vs. $65 \%$ ) and cutting tobacco stem ( $73.6 \% \%$ vs. $45 \%)$ were less prevalent in case workers than in control workers. On the other hand, tobacco-bundling was more frequent in the case workers than in the control workers ( $20 \%$ vs. $3.3 \%$ ), as shown in Table 1.

There was a statistically significant association between the disease and the number of tobacco stem collected per day $(p=<0.013)$. Case workers harvest fewer tobacco stem per day than control workers (1,106.6 vs. 710, respectively).

It can be seen in Table 1, with the univariate analysis, that the disease was not associated with age, schooling, main activity of work and time by which one gets with hands dirty of tobacco.

The statistically significant association between the disease and the use of socks during work was maintained ( $p=0.006)$. Workerscase presented higher frequency of socks than control workers (45\% vs. $15.4 \%$ ), as shown in Table 2. It should be noted that workers make use of ordinary stockings of any synthetic material and cotton, since this type of analysis was not the focus of the study.

In Table 2, there was no association between work with tobacco and wet clothes, changing wet clothes, smoking status, pesticide application, working time with tobacco, presenting signs and symptoms of acute intoxication in previous years and air humidity.

After adjusting for confounding factors, the following variables were statistically associated with the GTS: harvesting tobacco stem of the day $(p=0.006)$ and fencing tobacco $(p=0.047)$. Workers who perform the tobacco stem bundling of the day (in sticks) have an $87 \%$ reduction in the chance of developing GTS. For those who bundle tobacco, the likelihood of GTS is 9.45 times greater. The number of tobacco stem collected per day also remained statistically associated with GTS $(p=0.021)$. With each additional tobacco stem harvested per day by the worker, there is a reduction in the chance of developing GTS by $0.3 \%$. 
Table 1 - Socio-environmental risk factors associated with acute intoxication in the univariate analysis of workers who grow Burley tobacco in a municipality in the Northwest region of Rio Grande do Sul State, Brazil, 2018

\begin{tabular}{|c|c|c|c|}
\hline Variables* & Cases $(n=20)$ & Controls ( $n=91)$ & $p$ value** \\
\hline $\begin{array}{c}\text { Age range } \\
\quad<30 \\
30-39 \\
40-49 \\
50-59 \\
\geq 60\end{array}$ & $\begin{array}{l}3(15.0) \\
5(25.0) \\
4(20.0) \\
6(30.0) \\
2(10.0)\end{array}$ & $\begin{array}{c}9(9.9) \\
13(14.3) \\
24(26.4) \\
37(40.7) \\
8(8.8)\end{array}$ & 0.676 \\
\hline Schooling (years) & $7.35 \pm 2.77$ & $7.06 \pm 3.33$ & 0.713 \\
\hline $\begin{array}{l}\text { Main activity } \\
\text { Tobacco } \\
\text { Dairy cattle } \\
\text { Housewife/day laborer } \\
\text { Pig Industry } \\
\text { Corn/soy } \\
\text { Bakery } \\
\text { Fruticulture }\end{array}$ & $\begin{array}{l}7(35.0) \\
7(35.0) \\
3(15.0) \\
2(10.0) \\
1(5.0) \\
0(0.0) \\
0(0.0)\end{array}$ & $\begin{array}{c}40(44.0) \\
30(33.0) \\
13(14.3) \\
1(1.1) \\
5(5.5) \\
1(1.1) \\
1(1.1)\end{array}$ & 0.540 \\
\hline $\begin{array}{l}\text { Work activity carried out *** } \\
\text { Tobacco harvesting } \\
\text { Loading tobacco into shed } \\
\text { Hanging tobacco of the day } \\
\text { Hanging tobacco in the shed } \\
\text { Cutting tobacco stem } \\
\text { Cutting pre-wilting tobacco } \\
\text { Sticking pre-wilting tobacco } \\
\text { Collecting pre-wilting tobacco } \\
\text { Transporting the pre-wilting tobacco from the greenhouse } \\
\text { Bundling the tobacco } \\
\text { Transport the tobacco from the greenhouse to another shed } \\
\text { Tobacco thinning }\end{array}$ & $\begin{array}{c}20(100) \\
13(65.0) \\
10(50.0) \\
17(85.0) \\
9(45.0) \\
5(25.0) \\
8(40.0) \\
5(25.0) \\
2(10.0) \\
4(20.0) \\
0(0.0) \\
0(0.0)\end{array}$ & $\begin{array}{c}91(100) \\
82(90.1) \\
80(87.9) \\
76(83.5) \\
67(73.6) \\
20(22.0) \\
17(18.7) \\
12(13.2) \\
6(6.6) \\
3(3.3) \\
4(4.4) \\
2(2.2)\end{array}$ & $\begin{array}{c}- \\
0.009 \\
<0.001 \\
1.000 \\
0.026 \\
0.772 \\
0.072 \\
0.186 \\
0.633 \\
0.019 \\
1.000 \\
1.000\end{array}$ \\
\hline Number of stems harvested/day & $710 \pm 240$ & $1106.6 \pm 691.6$ & 0.013 \\
\hline Time (hours) with hands dirty with tobacco & $6.15 \pm 2.66$ & $6.90 \pm 2.31$ & 0.203 \\
\hline
\end{tabular}

Note: *Categorical variables expressed in $n(\%)$ and continuous variables expressed as mean \pm SD or median (25-75 percentiles); ** comparison of means by means of the $t$-student test, of medians by means of the Mann-Whitney Test, and of proportions by Chi-Square or Fisher's Exact; **** Multiple answer.

Table 2 - Personal protective equipment and socioenvironmental conditions associated with acute intoxication in the univariate analysis of workers who grow Burley tobacco in a municipality in the Northwest region of the state of Rio Grande do Sul, Brazil, 2018

\begin{tabular}{|c|c|c|c|}
\hline Variables* & Cases $(n=20)$ & Controls $(n=91)$ & $p$ value** \\
\hline \multicolumn{4}{|l|}{ Clothes/PPE*** } \\
\hline Hat & $16(80.0)$ & $75(82.4)$ & 0.756 \\
\hline Long pants & $17(85.0)$ & 67 (73.6) & 0.392 \\
\hline Boots & $12(60.0)$ & $55(60.4)$ & 1.000 \\
\hline Long shirt & $14(70.0)$ & $47(51.6)$ & 0.213 \\
\hline Short shirt & $6(30.0)$ & 44 (48.4) & 0.213 \\
\hline Flip flop & $4(20.0)$ & $28(30.8)$ & 0.490 \\
\hline Bermudas & $3(15.0)$ & $25(27.5)$ & 0.380 \\
\hline Shoes/sneakers/boots & $7(35.0)$ & $23(25.3)$ & 0.543 \\
\hline Cap & $7(35.0)$ & $22(24.2)$ & 0.474 \\
\hline Socks & $9(45.0)$ & 14 (15.4) & 0.006 \\
\hline Sunscreen & $2(10.0)$ & $7(7.7)$ & 0.664 \\
\hline Waterproof long sleeve & $0(0.0)$ & $2(2.2)$ & 1.000 \\
\hline Arabic cap & $0(0.0)$ & $1(1.1)$ & 1.000 \\
\hline Polyurethane sleeve & $7(35.0)$ & $25(27.5)$ & 0.689 \\
\hline Cotton sleeve & $1(5.0)$ & $1(1.1)$ & 0.329 \\
\hline Latex sleeve & $1(5.0)$ & $3(3.3)$ & 0.554 \\
\hline Latex + cotton sleeve & $2(10.0)$ & $5(5.5)$ & 0.607 \\
\hline Work with wet/humid tobacco & $14(70.0)$ & $63(69.2)$ & 1.000 \\
\hline Cloth got wet & $17(85.0)$ & $74(81.3)$ & 1.000 \\
\hline Changed clothes & $8(47.1)$ & $42(56.8)$ & 0.650 \\
\hline Smoking Status & & & 1.000 \\
\hline Smoker & $1(5.0)$ & $8(8.8)$ & \\
\hline Non-smoker/Ex-smoker & $19(95.0)$ & $83(91.2)$ & \\
\hline Applies agrotoxin & $11(55.0)$ & $58(63.7)$ & 0.635 \\
\hline Working time with tobacco (years) & $20(8-35)$ & $24(18-29)$ & 0.452 \\
\hline Had signals and symptoms in previous years & $12(60.0)$ & $40(44.0)$ & 0.292 \\
\hline Air humidity & $52.6 \pm 13.4$ & $51.8 \pm 13.7$ & 0.870 \\
\hline
\end{tabular}

Note: *Categorical variables expressed in $n(\%)$ and continuous variables expressed as mean $\pm S D$ or median (25-75 percentiles); ** comparison of means by means of the $t-s t u d e n t$ test, of medians by means of the Mann-Whitney Test, and of proportions by Chi-Square or Fisher's Exact; **** Multiple answer. 
After multivariate logistic regression analysis, the use of socks to work also remained associated with GTS $(p=0.011)$. The use of socks during work with tobacco is associated with a 6.32-fold increase in the chance of developing GTS, as presented in Table 3.

Table 3 - Multivariate Logistic Regression Analysis to evaluate socio-environmental factors associated with Green Tobacco Sickness in a municipality in the Northwest region of Rio Grande do Sul State, Brazil, 2018

\begin{tabular}{lcc}
\hline Variables & OR $(\mathbf{9 5} \% \mathbf{C l})$ & $\boldsymbol{p}$ value \\
\hline Sticking tobacco stems of the day & $0.13(0.03-0.57)$ & 0.006 \\
Bundling the tobacco & $9.45(1.03-86.6)$ & 0.047 \\
Number of stems harvested/day & $0.997(0.994-1.000)$ & 0.021 \\
Use of socks & $6.32(1.52-26.2)$ & 0.011 \\
\hline
\end{tabular}

\section{DISCUSSION}

Knowledge about risk factors is essential for the development of GTS prevention actions. To reach the objective of this study, it was necessary to describe the stages of the cultivation process, which begins with the preparation of the beds, followed by tillage/transplantation, sprout thinning (removal of extra sprouts/ shoots), harvesting and post-harvest. Harvesting starts on average 30 to 40 days after sprout thinning in December, and occurs in a single stage ${ }^{(19-20)}$. The process consists of manually cutting the plant (stem), taking it to the sheds and hanging it in wires or propping it in wooden sticks inside the sheds for drying/natural cure, which will remain hanging around 40 days, until they are completely dry leaves. After these steps, the plucking (removal of the leaves from the stem) is carried out, followed by the separation and distinction of the leaves in several classes ${ }^{(19)}$, formation of packages for the pressing and commercialization of the product.

Working with the green tobacco plant is a potential risk to GTS ${ }^{(9)}$. The harvest period is the occupational activity in which the worker has more contact with the tobacco leaf, which can increase the chances of acute intoxication ${ }^{(18)}$. Other characteristics of the work, as evidenced in the present study, such as loading tobacco into the shed, cutting tobacco stem, bundling tobacco and wearing socks during work, were risk factors for GTS. On the other hand, sticking the tobacco stem of the day and the number of stem harvested more per day had protective effect. These specific variables were not found in the literature for discussion, except the use of socks, considering that the harvesting process in this study is different from the tobacco variety presented in the literature.

It is warned that cutting tobacco requires that the worker flex the spine to reach the foot of the plant, which, according to a study ${ }^{(21)}$, can cause problems in the spine, besides requiring a considerable physical effort, associated to the period of heat, greater perspiration and, consequently, increase in the absorption of nicotine. Researchers have identified that the harvesting of lower tobacco leaves is more likely to develop GTS by the above factors $^{(10)}$. This fact may also be related, in the present study, to the workers who loads the tobacco into the shed, since the weight of the sticks with the tobacco stalks that are removed from the carts and/or trucks to hang in the shed requires a heavy physical effort. And also maintained contact of the green leaves of the tobacco with the skin, which, for the most part, still reported working with wet tobacco and wet clothes. These socio-environmental factors increase nicotine absorption and are well described in ancient and recent studies ${ }^{(3,5,13,18,22)}$. In this same perspective, the relationship between inhalation of tobacco dust in sheds during curing and GTS can be highlighted, as evidenced in a study in Korea, which reports the presence of high concentrations of nicotine in the air in the work places evaluated in cultivation, harvesting and tobacco curing(6).

In the present study, bundling tobacco was a risk factor for GTS. For those who bundle it, the likelihood of developing GTS is greater. This task usually takes place in the early morning, when the tobacco is wet from the serene, favoring the absorption of nicotine in the skin. When the leaf is wet, especially in the early hours of the morning, along with body sweat, it facilitates dermal absorption ${ }^{(23)}$. One study ${ }^{(5)}$ confirmed that wet tobacco harvesting is a risk factor for GTS, for both men and women. According to a classic study ${ }^{(24)}$, it is estimated that $9 \mathrm{~mL}$ of nicotine may be contained in $100 \mathrm{~mL}$ of dew and that during the harvest period the worker may be exposed to more than $600 \mathrm{~mL}$ of dew or rain present in tobacco leaves, equivalent to the nicotine of 36 cigarettes $^{(25)}$.

It was evidenced, in this research, which workers performed tobacco cutting in the late afternoon, when the sun was less hot; if they did in another period, when the sun is warmer, burns could occur in the leaves, interfering in the final quality of the product. The purpose of this procedure is for the tobacco to wilt, minimizing the leaf breakage, to favor the next manipulation, which is to pack the tobacco, that is, gather an average of 6 stem of tobacco for loading, or putting on sticks in the later transport to the sheds. Sticking tobacco and the number of stem collected had protective effect for the development of GTS in this study after adjusting for the multivariate model. Spitting tobacco of the day reduces by $87 \%$ the chance of developing GTS. This activity may be related to the slightest contact with the tobacco leaf, since the step consists in picking up the stem of the plant and sticking it. It may also be related to the exposure because the tobacco of the day was not cut overnight in the crop and consequently was not wet from dew, minimizing the risk of developing the disease.

It should be noted that each foot of tobacco harvested per day reduces the chance of developing GTS by $0.3 \%$, and control workers collected on average more than the worker-case, a fact that may be related to the presence of signs and symptoms of the disease and, as a consequence, makes it impossible to develop the work under conditions of normality. No studies were found to corroborate this association as evidenced in the present study. In this context, the finding becomes relevant and requires the development of other studies for confirmatory repetitions and a theoretical deepening.

Wearing socks was a risk factor for the development of GTS, in which was confirmed in this study. However, in another study that describes the use of water-resistant protective clothing as well as chemical-resistant gloves, plastic aprons, and rainwear with boots and socks, reduce the chances of developing GTS as it would decrease exposure nicotine ${ }^{(9)}$.

Meanwhile, some studies claim that because of the tobacco harvest period, when temperatures are high, associated with wet tobacco handling and wearing boots and socks, sweating is increased, favoring the increase of transdermal nicotine absorption, as described in different international and national studies ${ }^{(5,9,22)}$. 
This elucidates the suggestion described in a study with Indian workers, in which nicotine was absorbed by the stem ${ }^{(26)}$, and may be related to the use of wet clothes and shoes, which were also referred to as a factor associated with GTS(5).

In this study, as well as in a recent study ${ }^{(27)}$, GTS is not associated with age, smoking time, schooling and smoking status. In this sense, it can be agreed that age is not directly associated with the etiology of the disease, as well as having experience with tobacco handling had no relevance to avoid the disease, and more years of study were not associated to avoid it ${ }^{(27)}$. However, in another study ${ }^{(5)}$, lack of experience in working with tobacco was a factor associated with GTS, as younger workers ( $<30$ years) were 3.1 times more likely than older workers to develop GTS ${ }^{(28)}$.

There are divergences in the studies about the relation of the habit of use of tobacco products and GTS, but most of these researches ${ }^{(5,12-13,18,22)}$ shows evidence that there is a greater risk of developing GTS in nonsmokers. In contrast, for Thai tobacco workers, who were smokers, there was no protective effect on $\mathrm{GTS}^{(3)}$. Smoking was described as a protective effect against the development of GTS because workers who used tobacco products were less likely to suffer from the disease because of reduced nicotine dermal absorption due to vessel constriction resulting from smoking, metabolic adaptation or of nicotine tolerance acquired to the effects of long-term nicotine ${ }^{(29)}$. In any case, tobacco-related diseases overlap the "protective effect" identified and is not a GTS prevention measure ${ }^{(13)}$.

GTS was also not associated, in this study, with age, use of pesticides, alcohol consumption, work with wet clothes or dew and sweat, nor in the studies ${ }^{(10,18)}$ conducted in the Agreste region of Alagoas (Agreste is a narrow zone of Brazil in Rio Grande do Norte, Paraíba, Pernambuco, Alagoas, Sergipe and Bahia States between the coastal forest zona da mata and the semiarid sertão. The agreste fades out after it reaches Rio Grande do Norte due to the break of the mountain-chain that blocks air currents from the Atlantic ocean. This barrier is what induces high rainfalls in the coastal Atlantic forest zone) and in the city of Vale do Rio Pardo, in Rio Grande do Sul. Otherwise, in some studies it has been confirmed that there was an association of GTS with age ${ }^{(5,22)}$, the work type performed ${ }^{(22)}$, wet clothes ${ }^{(3)}$, exclusive participation in tobacco cultivation ${ }^{(18)}$, work in tobacco leaf harvesting ${ }^{(5,18)}$, work for less than five years in tobacco farming ${ }^{(18)}$, presence of the disease in previous years, contract workers, breaking tobacco leaves from the top of the plant ${ }^{(10)}$, act of hanging tobacco in the barn, exposure to physical effort, tying tobacco with hands, transporting burdens and contacting pesticides ${ }^{(5)}$. Some associations were not demonstrated in this study and others were not associated with GTS and may be related to the tobacco type studied.

\section{Study limitations}

One of the limitations of the present investigation is the lack of studies in the literature on the subject, in the sense of deepening on the variety of tobacco, since it presents higher content of nicotine. Moreover, the reduced sample size may have influenced the lack of statistical significance in some of the presented results.

\section{Contributions to the fields of Nursing, Health or Public Policy}

The investigation results allowed to recognize socio-environmental risk factors to which the smokers are exposed, related to the work process, which is determinant for individual and collective survival, in the family sense. Knowing the risks through the understanding of the work process allows nursing, in Primary Care, to act in an interdisciplinary way, pointing to socio-environmental strategies to contribute to the monitoring of illness processes and act as health promoters for this population, as well as to instrument workers for their self-knowledge and protection against GTS.

\section{CONCLUSION}

This study represents the first investigation with case-control methodology, with Burley-type tobacco workers, in the harvest period in a municipality located in the Northwest region of Rio Grande do Sul State. Factors contributing to GTS or its reduction, such as loading tobacco into the shed, harvesting tobacco, fencing tobacco and wearing socks to work, were identified.

These conditions are occupational among tobacco workers. Therefore, nurses and other primary health care professionals are required to develop integrated actions to protect and promote the health of rural workers and their families, as well as the factors identified. The objective is to list mechanisms to be implemented with a view to minimizing workers' exposure and, consequently, the signs of intoxication that tobacco cultivation can affect workers. It is suggested that studies of nicotine in the air in the tobacco curing process in Burley-type tobacco sheds be carried out, since nicotine inhalation may be occurring by workers during this stage.

\section{REFERENCES}

1. Sindicato Interestadual da Indústria do Tabaco (SindiTabaco). Sexto produto do agronegócio brasileiro, tabaco é exportado para 90 países [Internet]. 2017 [cited 2018 jan. 06]. Available from: https://www.noticiasagricolas.com.br/noticias/agronegocio/190278-sexto-produto-doagronegocio-brasileiro-tabaco-e-exportado-para-90-paises.html\#.XQ-fxa_Qi00

2. Reis MM, Oliveira APN, Turci SRB, Dantas RM, Silva VSP, Gross C, et al. Knowledge, attitudes, and practices of women farmers concerning tobacco agriculture in a municipality in Southern Brazil. Cad Saúde Pública. 2017;33(Supl 3):e00080516. doi: 10.1590/0102-311x00080516

3. Saleeon T, Siriwong W, Maldonado-Pérez HL, Robson MG. Green tobacco sickness among Thai traditional tobacco farmers, Thailand. Int J Occup Environ Med. 2015;6(3):169-76. doi: 10.15171/ijoem.2015.540

4. Park S-J, Lim H-S, Lee K, Yoo S-J. Green tobacco sickness among tobacco harvesters in a Korean village. Saf Health Work. 2018;9(1):71-4. doi: 10.1016/j.shaw.2017.06.007 
5. Fassa AG, Faria NM, Meucci RD, Fiori NS, Miranda VI, Facchini LA. Green tobacco sickness among tobacco farmers in southern Brazil. Am J Ind Med. 2014;57(6):726-35. doi: 10.1002/ajim.22307

6. Yoo S-J, Park S-J, Kim B-S, Lee K, Lim H-S, Kim J-S, et al. Airborne nicotine concentrations in the workplaces of tobacco farmers. J Prev Med Public Health. 2014;47(3):144-9. doi: 10.3961/jpmph.2014.47.3.144

7. Riquinho DL, Hennington EA. Cultivo do tabaco no sul do Brasil: doença da folha verde e outros agravos à saúde. Cien Saude Colet. 2014;19(12):4797-808. doi: 10.1590/1413-812320141912.19372013

8. Saleeon T, Siriwong W, Maldonado-Pérez HL, Robson MG. Salivary cotinine levels as a biomarker for green tobacco sickness in dry tobacco production among Thai traditional tobacco farmers. Rocz Panstw Zakl Hig [Internet]. 2016 [cited 2018 Jul 11];67(2):121-30. Available from: http://wydawnictwa.pzh.gov.pl/roczniki_pzh/download-article?id=1123

9. Achalli S, Shetty SR, Babu SG. The green hazards: a meta-analysis of green tobacco sickness. Int J Occup Saf Health. 2012;2(1):11-14. doi: 10.3126/ijosh.v2i1.4963

10. Bartholomay P, Iser BP, Oliveira PP, Santos TE, Malta DC, Sobel J, et al. Epidemiologic investigation of an occupational illness of tobacco harvesters in southern Brazil, a worldwide leader in tobacco production. Occup Environ Med. 2012;69(7):514-18. doi: 10.1136/ oemed-2011-100307

11. Mcknight RH, Spiller HA. Green tobacco sickness in children and adolescents. Public Health Rep. 2005;120(6):602-5. doi: 10.1177/003335490512000607

12. Arcury TA, Quandt SA, Preisser JS. Predictors of incidence and prevalence of green tobacco sickness among Latino farmworkers in North Carolina, USA. J Epidemiol Community Health. 2001;55(11):818-24. doi: 10.1136/jech.55.11.818

13. Schmitt NM, Schmitt J, Kouimintzis DJ, Kirch W. Health risks in tobacco farm workers - a review of the literature. J Public Health. 2007;15(4):255-64. doi: 10.1007/s10389-007-0122-4

14. Martins VA, Renner JDP, Corbelini VA, Pappen M, Krug SBF. Doença da Folha Verde do Tabaco no período da classificação do tabaco: perfil sociodemográfico e ocupacional de fumicultores de um município do interior do Rio Grande do Sul. R Epidemiol Control Infec. 2016;6(4):206-10. doi: 10.17058/reci.v6i4.8198

15. Silva JB, Xavier DS, Barboza MCN, Amestoy SC, Trindade LL, Silva JRS. Fumicultores da zona rural de Pelotas (RS), no Brasil: exposição ocupacional e a utilização de equipamentos de proteção individual (EPI). Saúde Debate [Internet]. 2013 [cited 2018 Jul 10];37(97):347-53. Available from: http://www.scielo.br/pdf/sdeb/v37n97/v37n97a16.pdf

16. Cezar-Vaz MR, Bonow CA, Mello MCVA, Silva MRS. Socio-environmental approach in nursing: focusing on rural labor and the use of pesticides. Rev Bras Enferm [Internet]. 2016;69(6):1114-21. doi: 10.1590/0034-7167-2016-0364

17. Frare e Silva RL, Carmes ER, Schwartz AF, Blaszkowski DS, Cirino RH, Ducci RDP. Smoking cessation among patients at a university hospital in Curitiba, Brazil. Rev Bras Pneumol. 2011;37(4): 480-7. doi: 10.1590/S1806-37132011000400010

18. Oliveira PPV, Sihler CB, Moura L, Malta DC, Torres MCA, Lima SMCP, et al. First reported outbreak of green tobacco sickness in Brazil. Cad Saúde Pública. 2010;26(12):2263-9. doi: 10.1590/S0102-311X2010001200005

19. Pauli RIP, Flech EM, Lucas LO. Modalidades de produção fumicultora no Rio Grande do Sul e particularidades das variáveis tecnológicas e do trabalho. Rev Latino-Am Hist [Internet]. 2012 [cited 2017 Aug 11];1(3):207-31. Available from: https://dialnet.unirioja.es/descarga/ articulo/6238631.pdf

20. Redin CJ, Redin E. A cadeia produtiva do tabaco em Arroio do Tigre/RS. Vivências [Internet]. 2014 [cited 2017 ago. 11];10(18):10-14 Available from: http://www2.reitoria.uri.br/ vivencias/Numero_018/artigos/pdf/Artigo_01.pdf

21. Meucci RD, Fassa AG, Faria NMX, Fiori NS. Chronic low back pain among tobacco farmers in southern Brazil. Int J Occup Environ Health. 2015;21(1):66-73. doi: 10.1179/2049396714Y.0000000094

22. Fotedar S, Fotedar V. Green tobacco sickness: a brief review. Indian J Occup Environ Med. 2017;21(3):101-4. doi: 10.4103/ijoem.IJOEM_160_17

23. Lee K, Lim H-S. Proposal of the global network for the study of green tobacco sickness. Ciênc Saúde Colet. 2013;18(6):1859-60. doi: 10.1590/ S1413-81232013000600037

24. Gehlbach SH, Williams WA, Perry LD, Freeman JI, Langone JJ, Peta LV et al. Nicotine absorption by workers harvesting green tobacco. Lancet. 1975;305(7905):478-80. doi: 10.1016/S0140-6736(75)92829-9

25. National Institute for Occupational Safety and Health (NIOSH). The National Occupational Research Agenda (NORA) Symposium 2006 [Internet]. Washington; 2006 [cited 2018 Jan 06]. Available from: https://www.cdc.gov/nora/symp06/default.html

26. Ghosh SK, Gokani VN, Doctor PB, Parikh JR, Kashyap SK. Intervention studies against "Green symptoms" among Indian tobacco harvesters. Arch Environ Health. 1991;46(5):316-7. doi: 10.1080/00039896.1991.9934396

27. Mota e Silva MS, Carvalho MGC, Moreira JC, Barreto EO, Farias KF, Nascimento CA, et al. Green Tobacco Sickness among Brazilian farm workers and genetic polymorphisms. BMC Res Notes. 2018;11:20. doi: 10.1186/s13104-018-3135-x

28. McKnight RH, Levine EJ, Rodgers GC Jr. Detection of green tobacco sickness by a regional poison control center. Vet Hum Toxicol. 1994;36(6):505-10.

29. Arcury TA, Quandt SA, Garcia DI, Preisser JS Jr, Norton D, Rao P. Clinic-based, case-control comparison of green tobacco sickness among minority farmworkers: clues for prevention. South Med J. 2002;95(9):1008-11. doi: 10.1097/00007611-200295090-00011 